\title{
Econometric analysis of long and short-run effects of exports on economic growth in Cameroon (1980-2016)
}

\author{
Nounamo Yann Harold \\ PhD Student in Economics, University of Yaoundé II-Soa, Cameroon.
}

\begin{abstract}
This paper implements the bound-testing approach proposed by Pesaran, Shin, and Smith (2001) to investigate the static and dynamic relationship between exports and economic growth in the Cameroon. The sample covers annual observations between 1980 and 2016. The results suggest the existence of positive long-run equilibrium relations in Cameroon. Furthermore, the findings indicate that the hypothesis that export growth causes economic growth called the export-led growth hypothesis is validated for the Case of Cameroon.
\end{abstract}

Keywords: Exports, economic growth, Cameroon.

JEL Classification: A11, C87, F41.

(C) The Authors, 2018. This article is published with open access at Sumy State University.

\section{Introduction}

The determinants of the economic growth have been a key issue of economic research. The identification of exports as a stimulated variable of economic growth has also long been investigated. According to the neoclassical growth theory, export expansion could stimulate economic growth because it promotes specialisation and raises factor productivity. Thus, many developing countries depend heavily on exportorientated businesses to accelerate economic growth. Among the first studies to demonstrate the positive relationship between exports and economic growth were those of Konstantakopoulou (2016), Balassa (1978), Heller and Porter (1978), Michaely (1977), and Blumenthal (1972). Those authors had applied regression and correlation analysis on developing countries ${ }^{1}$. Moreover, similar empirical works have been conducted by Sheehey (1992), Balassa (1985), Kavoussi (1984) and Feder (1982) who based them on production function models.

The causal link between exports and economic growth has been made by pioneering studies like those of Dodaro (1993), Bahmani-Oskooee et al. (1991), Chow (1987). However, these empirical studies simply consisted of focusing on the direction of the causal relationship between exports and growth in each country. So, their results, based on the causality tests of Granger (1967) and Sims (1972) were very controversial.

During the 1990s, many studies on the export-led growth hypothesis in developing countries were developed, particularly through the analysis of cointegration techniques. More specifically, apart from causality tests, Pistoresi and Rinaldi (2012), Balagued and Cantavella-Jorda (2004), Marin (1992), Henriques and Sadosky (1996), Thornton (1997), carried out cointegration tests to identify the existence of long-term relationships between exports and economic growth. However, new and more robust causality methods have also been developed and tested (Konstantakopoulou, 2016): this is the case of the ARDL method.

The purpose of this article is to study the long-term relationship between exports and economic growth using the bounds test approach of Pesaran and al. (2001) and examines the short-term relationship using error correction models. This procedure was applied by Tang (2006) for China, and Hye et al. (2013) for six South Asian countries. This methodology has been used in several studies, such as those of Konstantakopoulou (2016) for Southern Euro-zone countries and Awokuse (2003) for Canada.

This study is different from the others on a crucial point: we study for the case of Cameroon the static and dynamic relationship between exports and economic growth. This country is mainly exporting raw materials and commodities and exports more to Western countries than to CEMAC countries ${ }^{2}$. With regard to this latter stylized fact, Cameroon has long had close trade relations with France and China. As we observe in Figure 1, Cameroon imports more that it exports, which necessarily leads to a deficit trade balance and a high dependence on world prices of commodities and raw materials.

\footnotetext{
${ }^{1}$ For example, Michaely (1977) used less developed and developing countries as a sample of his analysis.

${ }^{2}$ Chad, Gabon, Central Africa Republic, Equatorial-Guinea, Republic of Congo.
} 


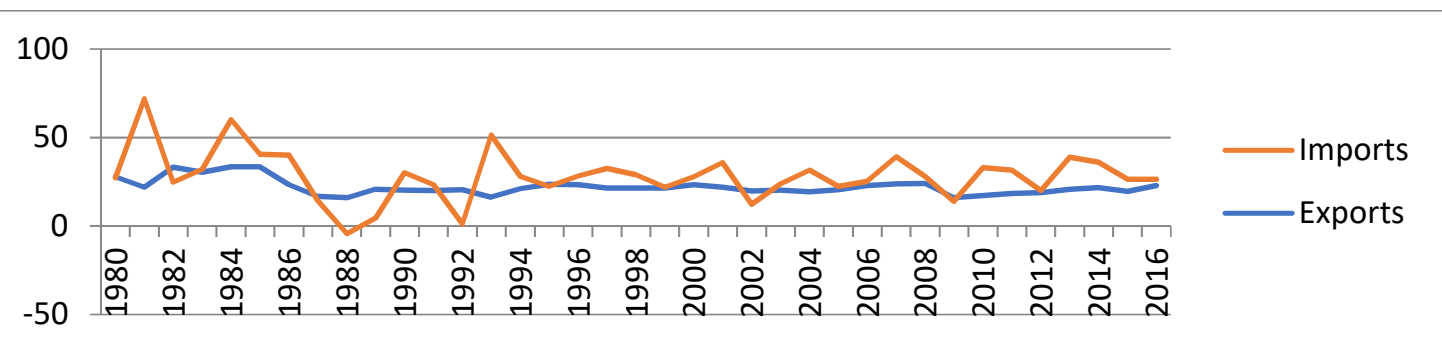

Figure 1. Exports and imports (as percent of GDP)

Source: World Bank

In terms of empirical methodology, our paper adds value the ARDL procedure, which can to reveal the long and short run relations between variables. This approach permits us to examine the hypothesis that export growth causes economic growth which is called the export-led growth hypothesis.

The organization of this article is as follows. Section 2 presents the literature review. Section 3 focuses on methodology and data description. Empirical results are contained in section 4 while concluding remarks are presented in section 5 .

\section{Literature review}

The discussions about the relationship between exports and economic growth rose after 1970s. We can divide the export-led growth studies into two groups. The first group found supportive results for export-led growth. Balassa (1978) tested this relationships by considering 11 developing countries. He show that exports affect economic growth. According to this author, export-oriented policies are more beneficial than import substitution in supporting economic growth. Tyler (1981) examined the exports-growth nexus for 55 countries between 1960 and 1977. He found a positive correlation between exports and economic growth as well. Dodaro (1991) also emphasized the importance of export-led growth for 41 developing countries indicating comparative advantage theory. For the countries under the investigation, a strong correlation between economic growth and manufactured products was found. Dodaro argued that the comparative advantage theory is valid, and the development level of a country affects the exported products and exports helps the countries to grow. Wacziarg (2000) analyzed the trade openness and economic growth for 57 countries between 1970 and 1989. He showed that trade openness affects the economic growth. In last decade, there have been many studies those support the export-led growth hypothesis including Mamun and Nath (2005), Maneschiold (2008), Herrerias and Orts (2010).

The second group of studies did not find supportive results for export-led growth. Among others; Hsiao (1987), Sengupta and Espana (1994), Akbar and Naqvi (2000), Panas and Vamvoukas (2002) could not find any evidence for the positive effect of export on economic growth, so did not support export-led growth theory.

\section{Methodology and data}

This section describes the ARDL model and the data being used to analyse the relationship between exports and economic growth.

2.1. Bounds tests Approach. The autoregressive distributed lag (ARDL) - also known as bounds testing approach - is one of the most popular econometric procedures that has been extensively used in investigating the environmental pollution functions. This is a single cointegration approach developed by Pesaran and al. (2001) and has some econometric advantages if compared to other single cointegration procedures (Pesaran and $a l ., 2001)^{3}$. First, it gives unbiased estimates of the long-run coefficients even if there is an endogeneity problem among the regressors. Second, it can estimate the long and short-run parameters simultaneously. Third, it can test for the existence of a long-run relationship between the variables in levels irrespective of whether they are $I(0), I(1)$, or a combination of both. Fourth, in small samples, it gives estimates with properties more superior to that of Gregory and Hansen cointegration procedures (Narayan

\footnotetext{
3 There are several examples of univariate cointegration approaches including Engle and Granger (1987) and the fully modified OLS procedures of Phillips and Hansen (1990). There are also many examples of multivariate cointegration procedures of Johansen (1988), Johansen and Juselius (1990), and Johansen's (1996) full information maximum likelihood technique.
} 
2005). In other words, Pesaran et al. (2001)'s test consists of estimating the following conditional error correction models (ECM):

$\Delta \mathrm{y}_{\mathrm{t}}=\alpha+\gamma_{1} \mathrm{y}_{\mathrm{t}-1}+\delta_{1} \mathrm{ex}_{\mathrm{t}-1}+\delta_{2} \mathrm{im}_{\mathrm{t}-1}+\sum \theta_{\mathrm{li}} \Delta \mathrm{y}_{\mathrm{t}-\mathrm{i}}+\sum \omega_{1 \mathrm{i}} \Delta \mathrm{ex}_{\mathrm{t}-\mathrm{j}}+\sum \varphi_{1 \mathrm{j}} \Delta \mathrm{im}_{\mathrm{t}-\mathrm{j}}+\varepsilon_{\mathrm{t}}(1)$ where $y t$ is the real output and ext is the real exports and imt is real imports, and $m(q)$ is the number of lags of the dependent (independent) variable. Annual data for these variables from 1980 till 2016 are obtained from the World Development Indicators Database provided by the World Bank (World Bank, 2017).

2.2. Estimation Procedure. Firstly, to estimate equation (1) by the Pesaran and al. (2001) procedure, we should examine each variable series included in equation (1) for its order of integration. This has been done by the Augmented Dickey-Fuller (ADF) and Phillips-Perron (PP) unit root tests. The results reported in Table (2) in Appendix indicate that, at the 1\% level of significance, exports don't contain a unit root and economic growth contain a unit root in his levels but stationary in his first differenc (i.e. it is $I(1)$ ). This provides a good rationale for carrying out the bounds testing approach.

Secondly, equation (1) is estimated by a specialized estimator that has been included in recent versions of EViews (EViews 10) for handling ARDL models. Fortunately, this estimator offers built-in laglength selection methods, critical values for the bounds test, as well as other post-estimation tests. Based upon the estimation results of equation (1) - as displayed in Table (3) in Appendix - the ARDL bounds test is carried out.

As it shows from Table (1), the F-statistic (3.829323) is bigger than the critical value of the upper bound at $5 \%$ significance level (3.38). Thus, we reject the null hypothesis of $\alpha 1=\alpha 2=\alpha 3=\alpha 4=0$ (i.e. no cointegration among the relevant variables) and conclude that there exists a long-run relationship between capital flight, external debt and others variables.

Table 3. F-statistics for testing the existence of a long-run relationship

\begin{tabular}{|l|c|c|c|c|c|}
\hline ARDL Model & AIC & SC & Log likelihood & F Wald test & P of Wald test \\
\hline ARDL $(1,1)$ & 5.105079 & 5.327272 & -84.33889 & 3.943991 & 0.030200 \\
\hline
\end{tabular}

2.3. Diagnostic Tests. Concerning the goodness of fit of the model specification, R-squared and adjusted Rsquared, are 0.729505 and 0.693439 respectively. The robustness of the model has been validated by several diagnostic tests. For example, Breusch-Godfrey serial correlation LM test, in Table (4) in Appendix, indicates that there is no serial correlation between the estimated model errors (F-statistic $=2.036270$ and $\mathrm{P}$ $=.1476)$.

Besides, CUSUM and CUSUMQ tests as certain the stability of the estimated coefficients because the plot of each statistic falls inside the critical bands of the 5\% confidence interval of parameter stability (See Figures 1\&2). Also, Jarque-Bera normality test assures the normality of errors (Refer to Figure 3). Furthermore, Breusch-Pagan-Godfrey heteroskedasticity test, in Table (5) in Appendix, shows that the residuals don't suffer from heteroskedasticity $\left(\mathrm{Obs}^{*} \mathrm{R} 2=16.8, \mathrm{P}=0.15\right)$. Given the above results, we can conclude that the outcomes reported are serially uncorrelated, normally distributed, and homoskedastic. Hence, the results reported are valid for reliable interpretations.

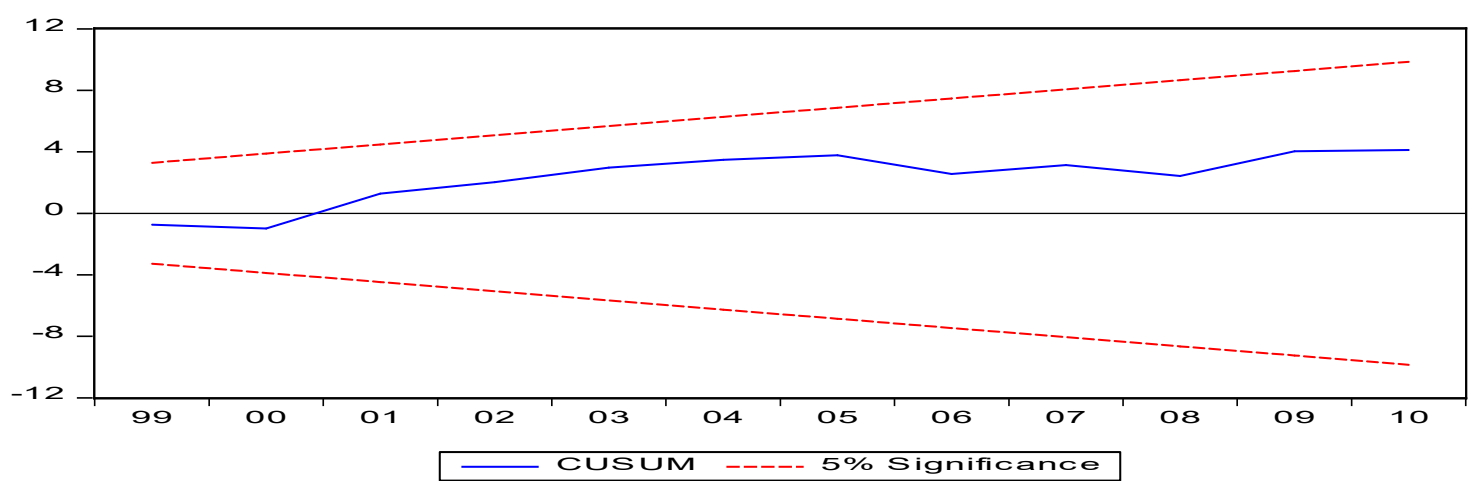

Figure 1. Results of CUSUM Test 


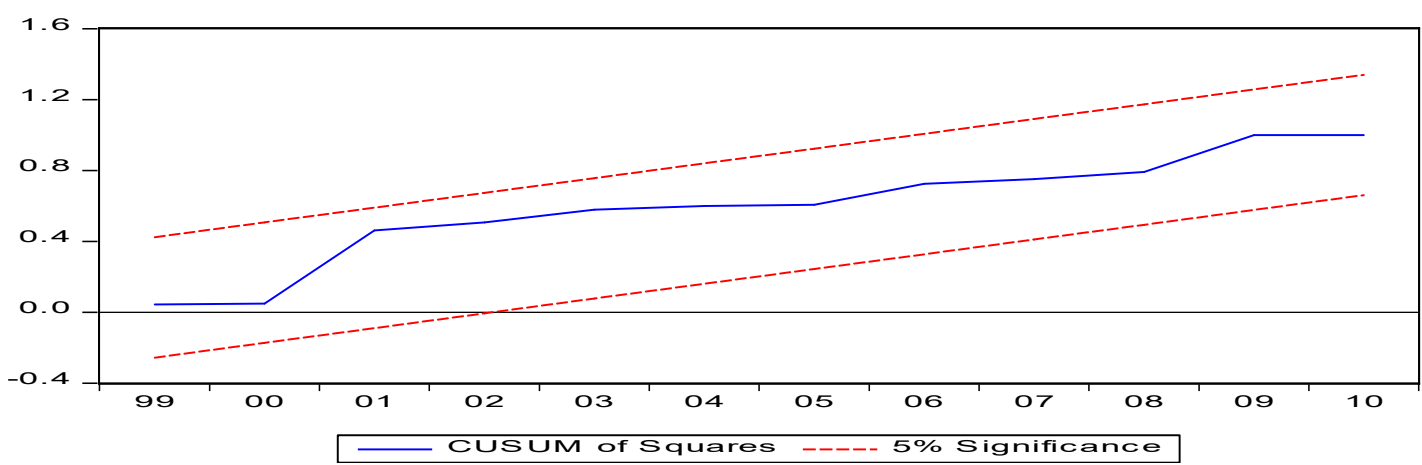

Figure 2. Results of CUSUMSQ Test

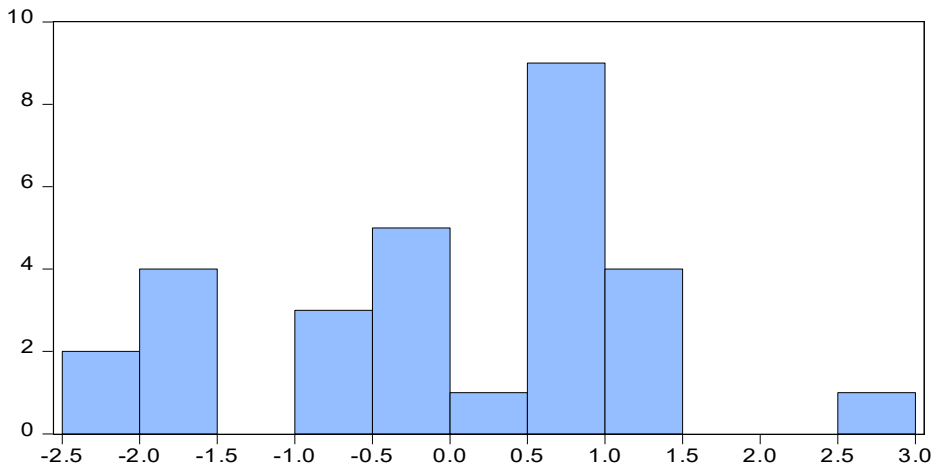

$\begin{array}{lr}\text { Series: Residuals } \\ \text { Sample 1988 } 2016 \\ \text { Observations } 29 \\ \text { Mean } & 4.21 \mathrm{e}-16 \\ \text { Median } & 0.030455 \\ \text { Maximum } & 2.800034 \\ \text { Minimum } & -2.354565 \\ \text { Std. Dev. } & 1.248317 \\ \text { Skewness } & -0.155095 \\ \text { Kurtosis } & 2.495219 \\ & \\ \text { Jarque-Bera } & 0.424151 \\ \text { Probability } & 0.808904\end{array}$

Figure 3. Results of Normality Test

\section{Empirical Results}

To capture the long and short-run relationships among the variable of our model, ARDL cointegrating form has been estimated. Results of the long-run estimated coefficients are shown in table 2 . It is found that the long-run impact of exports on economic growth in positive and significant.

Table 2. Estimated Long-Run Coefficients

\begin{tabular}{|c|r|r|r|r|}
\hline Variable & Coefficient & Std. Error & t-Statistic & Prob. \\
\hline C & 0.358159 & 0.422767 & 0.847177 & 0.4046 \\
\hline GDPG(-1)* & $-0.17854^{* * *}$ & 0.103224 & -1.729643 & 0.0956 \\
\hline EXT(-1) & 0.030524 & 0.079056 & 0.386105 & 0.7026 \\
\hline D(EXT) & $0.181317^{*}$ & 0.030933 & 5.861551 & 0.0000 \\
\hline D(EXT(-1)) & 0.113662 & 0.057832 & 1.965389 & 0.0601 \\
\hline D(EXT(-2)) & $0.158165^{*}$ & 0.038304 & 4.129213 & 0.0003 \\
\hline D(EXT(-3)) & $0.077150^{* *}$ & 0.027219 & 2.834416 & 0.0088 \\
\hline
\end{tabular}

Notes: $*$ indicates significance at the $1 \%$ level; $* *$ indicates significance at the $5 \%$ level; $* * *$ indicates significance at the $5 \%$ level.

Concerning the estimated short-run effects of our variable, they are displayed in table (3). It is found that exports are significant in the short-run. Also, the error correction mechanism (ECM) has been estimated to capture the speed of the adjustment of the model variables in the short-run in case any deviation from the longrun equilibrium occurs. When ECM (-1) is negative and significant, this means that the model variables are error correcting (adjusting) themselves till they reach their steady-state values (Enns et al 2014).

In our case, the estimated coefficient of ECM is negative and statistically significant at $1 \%$. This confirms the existence of a stable long-run relationship between the regressors and the dependent variable capital flight. As it shows from table (3), ECM (-1) value is -0.178540 . This suggests that when exports is above or below their equilibrium level, they adjust by almost $17 \%$ within the first year. The estimated ECM (-1) equation can be represented as follows:

$\mathrm{EC}=\mathrm{GDPG}-(-0.178540 * \mathrm{EXT}+2.0060)$ 
Table 3. Estimated Short-Run Coefficients

\begin{tabular}{|l|c|c|c|c|}
\hline \multicolumn{1}{|c|}{ Variable } & Coefficient & Std. Error & t-Statistic & Prob. \\
\hline D (EXT) & $0.18131^{*}$ & 0.026148 & 6.934116 & 0.0000 \\
\hline D (EXT(-1)) & $0.113662^{*}$ & 0.028615 & 3.972169 & 0.0005 \\
\hline D(EXT(-2)) & $0.158165^{*}$ & 0.026548 & 5.957752 & 0.0000 \\
\hline D (EXT(-3)) & $0.077150^{*}$ & 0.023058 & 3.345935 & 0.0025 \\
\hline CointEq (-1)* & $-0.178540^{* * *}$ & 0.092289 & -1.934586 & 0.0040 \\
\hline R-squared & 0.717678 & Mean dependent var & -0.070931 \\
\hline Adjusted R-squared & 0.677346 & S.D. dependent var & 3.128181 \\
\hline S.E. of regression & 1.776890 & Akaike info criterion & 4.126333 \\
\hline Sum squared resid & 88.40543 & \multicolumn{2}{|c|}{ Schwarz criterion } & 4.353077 \\
\hline Log likelihood & -63.08450 & \multicolumn{2}{|c|}{ Hannan-Quinn criter. } & 4.202625 \\
\hline Durbin-Watson stat & 1.926585 & \multicolumn{2}{l}{} \\
\hline
\end{tabular}

Notes: * indicates significance at the $1 \%$ level; ** indicates significance at the $5 \%$ level; *** indicates significance at the $5 \%$ level.

\section{Conclusion}

This paper examined the relationship between economic growth and exports in the Cameroon from 1980 till 2016. We utilized the ARDL bounds approach of Pesaran et al. (2001), which ensures that our results are robust to uncertainty about the order of integration of the variables. The empirical analysis shows that the exports-led-growth hypothesis is validated in this country; export-oriented policies should be applied, to increase economic growth rates. It is therefore of interest to policy-making on the promotion of export policies.

This study is not without its limits. First, the exclusion of some relevant control variables in the growth equation may have led to specification bias. This is the case of variables that capture natural resources, human capital, and institutions. As it's well known, quality of institution is a key factor that explains bad economic performances especially in developing countries. But because of data limitations, we have not been able to introduce this variable in the specification. Second, some control variables may be endogenous and therefore our estimated coefficient may be biased. One solution to overcome this problem would have been to estimate a GMM models.

\section{References}

1. Akbar, M., Naqvi, Z.F. (2000). Export diversification and the structural dynamics in the growth process: the case of Pakistan. The Pakistan Development Review, 39(4), 573-589.

2. Awokuse, T.O. (2003). Is the export-led growth hypothesis valid for Canada?", Canadian Journal of Economics, 36 (1), 126-136.

3. Bahmani-Oskooee, M., Mohtadi, H., and G. Shabsigh (1991). Exports, growth and causality in LDCs: A re-examination," Journal of Development Economics, 36, 405-415.

4. Balaguer, J., and M. Cantavella-Jorda (2004) Export composition and Spanish economic growth: evidence from the 20th century, Journal of Policy Modeling, 26,165-179.

5. Balassa, B. (1978). Export and economic growth: further evidence, Journal of Development Economics, 5(2), 181-189

6. Balassa, B. (1985). Exports, policy choices, and economic growth in developing countries after the 1973 oil shocks, Journal of Development Economics, 18(1), 23-35.

7. Blumenthal, T. (1972). Exports and economic growth: The case of postwar Japan, Quarterly Journal of Economics, 86 (4), 617-631.

8. Chow, P. (1987). Causality between exports growth and industrial development, Journal of Development Economics, 26, 55-63.

9. Dodaro, S. (1991). Comparative advantage, trade and growth: export-led growth revisited. World Development, 19(9), 1153-1165.

10. Dorado, S. (1993). Exports and growth: A reconsideration of causality, Journal of Developing Areas, 27, 227-244.

11. Engle R. F., Granger C. W. J. (1987). Co-Integration and Error Correction: Representation, Estimation, and Testing, Econometrica, 55(2), 251-276.

12. Enns P K, Takaaki Masaki and Nathan J. Kelly (2014). Time Series Analysis and Spurious Regression: An Error Correction. Cornell University

13. Feder, G. (1982). On exports and economic growth, Journal of Development Economics, 12, 59-73. 
14. Granger, C.W.J. (1969). Investigating causal relationships by econometric models and crossspectral models, Econometrica, 37, 424-438.

15. Heller, P.S., and R.C. Porter (1978). Exports and Growth: An empirical re-investigation, Journal of Development Economics, 5(2), 191-193.

16. Henriques, I., and P. Sadorsky (1996). Export-led growth or growth-driven exports? The Canadian case, Canadian Journal of Economics, 29 (3), 540-555.

17. Herrerias, M. J., Orts, V. (2010). Is the Export-led growth gypothes is enough to account for China's growth? China \& World Economy, 18(4), 34-51.

18. Hsiao, M.C.W. (1987). Tests of causality and exogeneity between exports and economic growth: The case of Asian NICs. Journal of Economic Development, 12, 143-159

19. Hye, Q.M.A., Wizarat, S., and W.-Y. Lau (2013). Trade-Led growth hypothesis: An empirical analysis of South Asian countries, Economic Modelling, 35, 654-660.

20. Johansen and Juselius, K., (1990). Maximum Likelihood Estimation and Inference on Cointegration - with Applications to the Demand for Money, Oxford Bulletin of Economics and Statistics, 52(2), 169-210.

21. Johansen, S., (1996). Likelihood-based inference in cointegrated vector autoregressive models. Oxford University Press, Oxford.

22. Johansen, S., (1988). Statistical analysis of cointegration vectors, Journal of Economic Dynamics \& Control, 12, 2131-54.

23. Kavoussi, R.M. (1984). Export expansion and economic growth: Further empirical evidence, Journal of Development Economics, 17, 241-250.

24. Konstantakopoulou I. (2016). New evidence on the Export-led-growth hypothesis in the Southern Eurozone countries (1960-2014), Economics Bulletin, 36, (1), 429-439

25. Mamun, K. A., Nath, K. (2005) Export-led growth in Bangladesh: a time series analysis, Applied Economics Letters, 12, 361-364.

26. ManeschÕöld, P.O. (2008). A note on the export-led growth hypothesis: a time series approach. Cuadernos De Economia, 45, 293-302

27. Marin, D. (1992). Is the export-led growth hypothesis valid for industrialized countries? Review of Economics and Statistics, 74 (4), 678-688

28. Michaely, M. (1977). Exports and Growth, Journal of Development Economics, 4, 49-53.

29. Panas, E., Vamvoukas, G. (2002). Further evidence on the export-led growth hypothesis, Applied Economics Letters, 9,731-735.

30. Perasan, M.H., Shin, Y., and R.J. Smith (2001). Bounds Testing Approaches to the Analysis of Level Relationships, Journal of Applied Econometrics, 16(3), 289-326.

31. Phillips, P.C.B., Perron, P.,(1988). Testing for a unit root in time series regression, Biometrica 75, 335446.

32. Pistoresi, B., and A. Rinaldi (2012). Exports, imports and growth: New evidence on Italy, 2863-2004, Explorations in Economic History, 49, 241-254.

33. Sengupta, J.K., Espana, J.R. (1994). Exports and economic growth in Asian NICs: an econometric analysis for Korea, Applied Economics, 26, 41- 51

34. Sheehey, E.J. (1992). Exports and growth: additional evidence, Journal of Development Studies 28(4), 730-734.

35. Sims, C. (1972). Money, Income and Causality, American Economic Review, 62, 540-552.

36. Tang, T.C. (2006). New evidence on export expansion, economic growth and causality in China, Applied Economics Letters, 13: 801-803, DOI: 0.1080/13504850500425303.

37. Thornton, J. (1997). Exports and economic growth: Evidence from 19th Century Europe, Economics Letters, 55, 235-240.

38. Tyler, W.G. (1981). Growth and export expansion of developing countries: some empirical evidence. Journal of Development Economics, 9(1), 121-30.

39. Wacziarg, R. (2000). Measuring the dynamic gains from trade. Research Paper Series, Research Paper 1654.

\section{Appendix}

Table 1. Descriptive Statistics

\begin{tabular}{|l|c|c|}
\hline & GDPG & EXT \\
\hline Mean & 3.033992 & 5.122196 \\
\hline Median & 4.062279 & 2.599984 \\
\hline
\end{tabular}


Table 1 (cont.). Descriptive Statistics

\begin{tabular}{|l|l|l|}
\hline Maximum & \multicolumn{1}{|c|}{17.08268} & \multicolumn{1}{c|}{44.27406} \\
\hline Minimum & -7.932067 & -18.73411 \\
\hline Std. Dev. & 4.784104 & 13.46563 \\
\hline Skewness & -0.258365 & 0.713850 \\
\hline Kurtosis & 4.462730 & 3.719416 \\
\hline Probability & 0.156441 & 0.139434 \\
\hline Sum & 112.2577 & 189.5213 \\
\hline Sum Sq. Dev. & 823.9554 & 6527.637 \\
\hline Observations & 37 & 37 \\
\hline
\end{tabular}

Table 2. Unit Root Tests

\begin{tabular}{|l|l|l|l|l|}
\hline \multirow{2}{*}{ Series } & Level & PP & 1st Difference & ADF \\
\cline { 2 - 5 } & ADF & 0.0002 & - & \\
\hline ex & 0.0003 & 0.0521 & 0.0050 & 0.0000 \\
\hline gdpg & 0.0556 &
\end{tabular}

Notes: *The null hypothesis of a unit root is rejected by the Mackinnon critical values at $5 \%$.

Table 3

Dependent Variable: GDPG

Method: ARDL

Sample (adjusted): 19822016

Included observations: 35 after adjustments

Maximum dependent lags: 2 (Automatic selection)

Model selection method: Akaike info criterion (AIC)

Dynamic regressors (2 lags, automatic): EXT

Fixed regressors: $\mathrm{C}$

Number of models evalulated: 6

Selected Model: ARDL $(1,2)$

\begin{tabular}{|l|c|c|c|c|}
\hline \multicolumn{1}{|c|}{ Variable } & Coefficient & Std. Error & t-Statistic & Prob. \\
\hline GDPG(-1) & 0.565689 & 0.101860 & 5.553600 & 0.0000 \\
\hline EXT & 0.165421 & 0.034452 & 4.801494 & 0.0000 \\
\hline EXT(-1) & 0.013490 & 0.033816 & 0.398931 & 0.6928 \\
\hline EXT(-2) & 0.071756 & 0.034663 & 2.070088 & 0.0471 \\
\hline C & -0.043980 & 0.503521 & -0.087345 & 0.9310 \\
\hline R-squared & 0.729505 & Mean dependent var & 2.775437 \\
\hline Adjusted R-squared & 0.693439 & S.D. dependent var & 4.198239 \\
\hline S.E. of regression & 2.324478 & Akaike info criterion & 4.656432 \\
\hline Sum squared resid & 162.0960 & Schwarz criterion & 4.878625 \\
\hline Log likelihood & -76.48756 & Hannan-Quinn criter. & 4.733133 \\
\hline F-statistic & 20.22695 & Durbin-Watson stat & 1.146721 \\
\hline Prob(F-statistic) & 0.000000 & \multicolumn{3}{|}{} \\
\hline
\end{tabular}

*Note: p-values and any subsequent tests do not account for model selection.

Table 4. Breusch-Godfrey Serial Correlation LM Test

\begin{tabular}{|l|c|c|c|r|}
\hline Null hypothesis: No serial correlation at up to 2 lags & \multicolumn{1}{l|}{} \\
\hline F-statistic & 2.036270 & Prob. F(2,31) & 0.1476 \\
\hline Obs*R-squared & 4.180234 & Prob. Chi-Square(2) & \\
\hline Test Equation: & & & \\
\hline Dependent Variable: RESID & & & \\
\hline Method: ARDL & & & \\
\hline Sample: 1981 2016 & & \\
\hline Included observations: 36 & & \\
\hline Presample missing value lagged residuals set to zero. & Std. Error & t-Statistic & Prob. \\
\hline Variable & Coefficient & 0.318330 & -1.619327 & 0.1155 \\
\hline GDPG(-1) & -0.515481 & 0.179662 & 0.608287 & 0.5474 \\
\hline EXG & 0.109286 & & \\
\hline
\end{tabular}


Table 4 (cont.). Breusch-Godfrey Serial Correlation LM Test

\begin{tabular}{|l|c|c|c|c|}
\hline C & -0.827002 & 3.591371 & -0.230275 & 0.8194 \\
\hline RESID(-1) & 0.525983 & 0.328683 & 1.600275 & 0.1197 \\
\hline RESID(-2) & 0.406617 & 0.217758 & 1.867288 & 0.0713 \\
\hline R-squared & 0.116118 & Mean dependent var & $1.83 \mathrm{E}-15$ \\
\hline Adjusted R-squared & 0.002068 & S.D. dependent var & 3.827378 \\
\hline S.E. of regression & 3.823418 & Akaike info criterion & 5.648413 \\
\hline Sum squared resid & 453.1743 & Schwarz criterion & 5.868346 \\
\hline Log likelihood & -96.67143 & Hannan-Quinn criter. & 5.725175 \\
\hline F-statistic & 1.018135 & Durbin-Watson stat & 1.632363 \\
\hline Prob(F-statistic) & 0.413281 & & & \\
\hline
\end{tabular}

